\title{
Hubungan Tindakan Pemberantasan Sarang Nyamuk dengan Keberadaan Larva Vektor DBD di Kelurahan Lubuk Buaya
}

\author{
Ayu Azlina ${ }^{1}$, Adrial $^{2}$, Eliza $^{\text {Anas }}{ }^{3}$
}

\section{Abstrak}

Kelurahan Lubuk Buaya merupakan daerah endemik Demam Berdarah Dengue (DBD) dengan korban meninggal terbanyak pada tahun 2012. Penyebaran DBD dipengaruhi oleh faktor lingkungan dan tindakan Pemberantasan Sarang Nyamuk (PSN). Tujuan penelitian ini adalah menentukan hubungan tindakan pemberantasan sarang nyamuk dan keberadaan larva vektor DBD di Kelurahan Lubuk Buaya Kecamatan Koto Tangah Kota Padang. Jenis penelitian adalah analitik observasional dengan rancangan cross sectional. Penelitian dilaksanakan di Kelurahan Lubuk Buaya dengan 110 sampel pada bulan Desember 2014. Sampel diambil dengan metode Multistage Random Sampling. Pengambilan data menggunakan kuesioner dan survei larva terhadap kontainer yang berada di dalam dan di luar rumah responden. Data disajikan dalam bentuk tabel ditribusi dan dianalisis statistik dengan uji chi-square. Hasil penelitian menunjukkan lebih dari separuh responden melakukan tindakan PSN yang baik. Keberadaan larva vektor DBD tergolong tinggi dengan $\mathrm{HI} 35,45 \%$, CI 13,41\%, BI 50\% dan Density figure/ $\mathrm{Df}=5$. Terdapat hubungan yang bermakna antara tindakan pemberantasan sarang nyamuk dengan keberadaan larva vektor DBD di kelurahan Lubuk Buaya ( $p=0,001$ ). Pelaksanaan PSN di Kelurahan Lubuk Buaya secara umum belum terlaksana secara optimal.

Kata kunci: PSN, larva, vektor DBD

\section{Abstract}

Kelurahan Lubuk Buaya is a Dengue Hemorhagic Fever (DHF) endemic area with the highest death case in 2012. The spreading of DHF influenced by environmental factor and practice of mosquito breading place eradication. The objective of this study was to determine the relationship between mosquito breading place eradication practice and the presence of larvae DHF's vector. The research was an analitic observational with cross-sectional study design. The research was held in Lubuk Buaya with 110 samples in December 2014. The samples were taken with the Multistage Random Sampling methods. Data's were collected by using a questionnare and survey of the larvae. Data were presented in distribution table and analyzed statistically with Chi Square method. The result showed more than half of the respondents have a good mosquito breading place eradication practice and the presence of larvae DHF's vector in lubuk buaya is high with $\mathrm{HI} 35.45 \%, \mathrm{Cl} 13.41 \%, \mathrm{BI} 50 \%$, and density figure 5 . There is a relationship between breading place eradication practice and the presence of larvae DHF's vector $(p=0.001)$. The implementation of breading place eradication practice in Lubuk Buaya isn't implemented optimally.

Keywords: breading place eradication, larvae, dengue hemorhagic fever vektor

Affiliasi penulis: 1. Pendidikan Dokter FK UNAND (Fakultas Kedokteran Universitas Andalas Padang), 2. Bagian Parasitologi FK UNAND, 3. Bagian Biologi FK UNAND

Korespondensi: Ayu Azlina, email: ayuazlina@ymail.com, Telp: 082388665542

\section{PENDAHULUAN}

Saat ini, penyakit dengue merupakan masalah kesehatan masyarakat serius di dunia dan khususnya Indonesia yang terletak di daerah khatulistiwa dengan iklim tropis. ${ }^{1}$ Berdasarkan World Health Organization 
(WHO) pada tahun 2009, diperkirakan 50 juta orang terinfeksi Demam Berdarah Dengue (DBD) setiap tahunnya dan 2,5 miliar orang tinggal di daerah endemik DBD. ${ }^{2}$ Demam Berdarah di Indonesia pertama kali ditemukan di kota Surabaya pada tahun 1968, dimana sebanyak 58 orang terinfeksi dan 24 orang diantaranya meninggal dunia dengan Angka Kematian (AK) adalah 41,3\%. Sejak saat itu, penyakit ini menyebar luas ke seluruh Indonesia. ${ }^{3}$

Pada tahun 2011 dilaporkan sebanyak 65.725 orang menderita DBD di Indonesia dan angka tersebut meningkat pada tahun 2012 menjadi sebanyak 90.245 orang menderita DBD. Jumlah kabupaten/kota terjangkit DBD pada tahun 2012 juga mengalami peningkatan, dari 374 Kabupaten/Kota (75,25\%) menjadi 417 (83,9\%) pada tahun 2012. Peningkatan ini menunjukkan semakin luasnya penyebaran $\mathrm{DBD}{ }^{4}$

Pada tahun 2012, penyakit DBD di Indonesia memiliki Incident Rate (IR) sebesar 37,11/100.000 penduduk dan terdapat 17 provinsi dengan IR lebih tinggi dari angka nasional tersebut. Salah satu diantaranya adalah provinsi Sumatera Barat dengan IR sebesar 66,72/100.000 penduduk yang menduduki peringkat ketujuh tertinggi. Semenjak tahun 2008 sampai tahun 2012, Kabupaten/kota yang selalu menjadi daerah dengan kasus DBD tertinggi di Sumatera Barat adalah kota Padang. ${ }^{5}$

Pada tahun 2012, kasus DBD Kota Padang yang terbanyak terdapat pada wilayah kerja puskesmas Lubuk Buaya dengan 203 kasus tanpa ada korban meninggal. Pada tahun 2013 terjadi penurunan kasus DBD menjadi 122 penderita, tetapi ditemukan korban meninggal sebanyak 2 orang. Kelurahan Lubuk Buaya yang berada dalam wilayah kerja Puskesmas Lubuk Buaya dengan jumlah kasus DBD dan korban meninggal terbanyak dengan 30 kasus penderita dan 2 kasus meninggal. ${ }^{6}$

Vaksin untuk pencegahan terhadap infeksi virus dan obat untuk penyakit DB/DBD belum ada dan masih dalam proses penelitian, sehingga pengendaliannya terutama ditujukan untuk memutus rantai penularan, yaitu dengan pengendalian vektornya. $^{7}$ Pengendalian Vektor DBD yang paling efisien dan efektif adalah dengan memutus rantai penularan melalui pemberantasan jentik. Pelaksanaannya di masyarakat dilakukan melalui upaya Pemberantasan Sarang Nyamuk (PSN) dalam bentuk kegiatan $3 \mathrm{M}$ plus, yaitu : menguras dan menyikat tempat penampungan air (TPA), seperti bak mandi/wc seminggu sekali (M1), menutup rapat TPA, seperti gentong air, tempayan (M2), memanfaatkan atau mendaur ulang barang bekas yang dapat menampung air hujan (M3), selain itu ditambah (plus) dengan cara lainnya, seperti mengganti air vas bunga atau tempat lainnya yang sejenis seminggu sekali, memperbaiki saluran dan talang air yang tidak lancar/rusak, menaburkan bubuk larvasida/abate untuk membunuh jentik nyamuk, memelihara ikan pemakan jentik, memasang kawat kasa, menghindari kebiasaan menggantung pakaian dalam kamar, mengupayakan pencahayaan dan ventilasi ruang yang memadai, menggunakan kelambu, memakai obat yang dapat mencegah gigitan nyamuk. Untuk mendapatkan hasil yang diharapkan, kegiatan $3 \mathrm{M}$ Plus ini harus dilakukan secara luas/serempak dan terus menerus /berkesinambungan. ${ }^{8}$

Apabila PSN dilaksanakan seluruh masyarakat maka diharapkan nyamuk Aedes aegypti yang merupakan vektor DBD dapat terbasmi. Untuk itu diperlukan usaha penyuluhan dan motivasi kepada masyarakat secara terus menerus dalam jangka waktu lama, karena keberadaan jentik nyamuk tersebut berkaitan erat dengan perilaku/ tindakan masyarakat. ${ }^{9}$

Tujuan penelitian ini adalah menentukan hubungan tindakan PSN dengan keberadaan larva vektor penyakit DBD di daerah endemik DBD Kelurahan Lubuk Buaya Kecamatan Koto Tangah Kota Padang.

\section{METODE}

Penelitian ini dilakukan di Kelurahan Lubuk Buaya Kota Padang dari Juni - Desember 2014. Sampel berjumlah 110 Kepala Keluarga (KK) dengan sampel target adalah ibu rumah tangga dengan menggunakan metode multistage random sampling. Penelitian ini berjenis analitik observasional dalam rancangan cross sectional study. Variabel terikat penelitian ini adalah keberadaan larva vektor DBD, sedangkan variabel bebas adalah tindakan PSN 3M plus. Alat yang digunakan adalah gayung, pipet untuk mengambil jentik, botol sampel untuk larva, cidukan/ saringan larva, senter, mikroskop dan alat tulis. Bahan 
yang digunakan adalah objek glass, kaca penutup, alkohol 70\%, kertas label, kertas tissue, lembar observasi larva. Pengambilan data dilakukan dengan menggunakan kuesioner dan survei larva terhadap kontainer-kontainer yang berada di dalam dan di luar rumah responden.

HASIL

Tabel 1. Distribusi keberadaan vektor DBD

\begin{tabular}{cccccc}
\hline \multirow{2}{*}{ Diperiksa } & \multirow{2}{*}{ Jumlah } & \multicolumn{4}{c}{ Keberadaan larva } \\
\cline { 3 - 6 } & & \multicolumn{2}{c}{ Ada } & \multicolumn{2}{c}{ Tidak } \\
\cline { 3 - 6 } & & $\mathbf{f}$ & $\%$ & $\mathbf{f}$ & $\%$ \\
\hline \multirow{2}{*}{ Rumah } & 110 & 39 & 35,45 & 71 & 64,54 \\
& $(100 \%)$ & & & & \\
Kontainer & 410 & 55 & 13,41 & 355 & 86,59 \\
& $(100 \%)$ & & & & \\
\hline
\end{tabular}

Berdasarkan Tabel 1 diketahui bahwa dari 110 rumah responden yang diperiksa, sebanyak 39 rumah ditemukan adanya jentik, sehingga diperoleh House Index (HI) 35,45\%. Sementara itu, dari 410 kontainer yang diperiksa, sebanyak 55 kontainer ditemukan adanya jentik, sehingga diperoleh Container Index (Cl) 13,41\%, dan Breteau Index (BI) 50\%. Rata-rata kategori Density figure (Df) vektor DBD di Kelurahan Lubuk Buaya adalah 5 (kategori tinggi).

Tabel 2. Distribusi frekuensi keberadaan larva vektor DBD berdasarkan jenis dan letak kontainer

\begin{tabular}{llcccc}
\hline No & Kontainer & $\mathbf{f}$ & $\%$ & $\begin{array}{c}(+) \\
\text { Larva }\end{array}$ & $\%$ \\
\hline & Dalam rumah & $\mathbf{2 2 8}$ & $\mathbf{5 5 , 6 1}$ & $\mathbf{3 8}$ & $\mathbf{1 6 , 6 7}$ \\
\hline 1 & $\begin{array}{l}\text { Bak Mandi } \\
\text { Keramik }\end{array}$ & 52 & 12,68 & 7 & 13,46 \\
2 & Bak Mandi & 23 & 5,61 & 7 & 30,43 \\
& Semen & & & & \\
3 & Drum & 4 & 0,98 & 1 & 25 \\
4 & Baskom & 21 & 5,12 & 1 & 4,76 \\
5 & Sumur & 4 & 0,98 & 0 & 0 \\
6 & Akuarium & 10 & 2,44 & 1 & 10 \\
7 & Dispenser & 38 & 9,27 & 17 & 44,74 \\
8 & Tandon & 49 & 11,95 & 0 & 0 \\
& Kulkas & & & & \\
9 & Ember & 25 & 6,09 & 2 & 8 \\
& & & & & 100 \\
10 & Vas bunga & 2 & 0,49 & 2 &
\end{tabular}

\begin{tabular}{|c|c|c|c|c|c|}
\hline \multicolumn{2}{|r|}{ Luar Rumah } & \multirow{2}{*}{$\begin{array}{c}182 \\
16\end{array}$} & \multirow{2}{*}{$\begin{array}{c}44,39 \\
3,90\end{array}$} & \multirow{2}{*}{$\begin{array}{l}17 \\
6\end{array}$} & \multirow{2}{*}{$\begin{array}{c}\mathbf{9 , 3 4} \\
37,50\end{array}$} \\
\hline 1 & Kaleng Bekas & & & & \\
\hline 2 & Ban Bekas & 2 & 0,49 & 0 & 0 \\
\hline 3 & Ember Bekas & 13 & 3,17 & 5 & 38,46 \\
\hline 4 & Drum & 5 & 1,22 & 1 & 20 \\
\hline \multirow[t]{3}{*}{5} & Tempat & & & & \\
\hline & Minum & 14 & 3,41 & 0 & 0 \\
\hline & Burung & & & & \\
\hline 6 & Kolam & 12 & 2,93 & 0 & 0 \\
\hline 7 & $\begin{array}{l}\text { Pot Bunga } \\
\text { Berisi Air }\end{array}$ & 7 & 1,71 & 5 & 71,43 \\
\hline 8 & Baskom & 5 & 1,22 & 0 & 0 \\
\hline 9 & Bak & 4 & 0,98 & 0 & 0 \\
\hline 10 & $\begin{array}{l}\text { Tempurung } \\
\text { kelapa }\end{array}$ & 10 & 2,44 & 0 & 0 \\
\hline 11 & Plastik Bekas & 1 & 0,24 & 0 & 0 \\
\hline \multirow[t]{2}{*}{12} & Bekas & & & & \\
\hline & $\begin{array}{l}\text { Adonan } \\
\text { semen }\end{array}$ & 1 & 0,24 & 0 & 0 \\
\hline 13 & Lesung & 1 & 0,24 & 0 & 0 \\
\hline 14 & Lubang pohon & 2 & 0,49 & 0 & 0 \\
\hline 15 & Genangan air & 3 & 0,73 & 0 & 0 \\
\hline 16 & Talang air & 85 & 20,73 & 0 & 0 \\
\hline 17 & $\begin{array}{l}\text { Penampunga } \\
\text { n air limbah }\end{array}$ & 1 & 0,24 & 0 & 0 \\
\hline & Jumlah & 410 & 100 & 55 & 13,41 \\
\hline
\end{tabular}

Berdasarkan Tabel 2 diketahui bahwa kontainer di dalam rumah yang positif jentik sebanyak 38 kontainer (16,67\%) sedangkan kontainer yang berada di luar rumah dan positif jentik sebanyak 17 kontainer $(9,34 \%)$. Kontainer di dalam rumah yang terbanyak mengandung jentik Aedes spp. adalah dispenser yaitu sebanyak 17 buah $(44,74 \%)$, kemudian diikuti bak mandi semen sebanyak 7 buah $(30,43 \%)$ dan bak mandi keramik sebanyak 7 buah $(13,46 \%)$.

Tabel 3. Distribusi frekuensi keberadaan larva vektor DBD berdasarkan jenis spesies

\begin{tabular}{cccc}
\hline \multirow{2}{*}{$\begin{array}{r}\text { Letak } \\
\text { Kon- } \\
\text { tainer }\end{array}$} & $\begin{array}{c}\text { Aedes } \\
\text { aegypti }\end{array}$ & $\begin{array}{c}\text { Aedes } \\
\text { albopictus }\end{array}$ & Jumlah \\
\cline { 2 - 3 } & $\mathrm{f}(\%)$ & $\mathrm{f}(\%)$ & $\mathrm{f}(\%)$ \\
\hline $\begin{array}{c}\text { Dalam } \\
\text { rumah } \\
\text { Luar } \\
\text { Rumah }\end{array}$ & $38(69,09)$ & $0(0)$ & $38(69,09)$ \\
\hline Jumlah & $7(12,73)$ & $10(18,18)$ & $17(30,91)$ \\
\hline
\end{tabular}


Berdasarkan Tabel 3 diketahui bahwa larva Ae. aegypti ditemukan lebih banyak di dalam rumah (70,91\%) dibandingkan di luar rumah (12,73\%). Sementara itu, untuk larva $A$ e. albopictus tidak ditemukan satupun di dalam rumah.

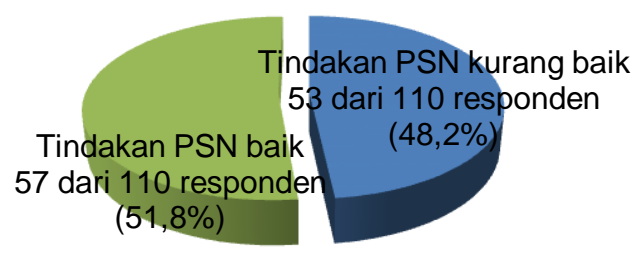

Gambar 1. Distribusi frekuensi tindakan PSN

Berdasarkan Gambar 1 diketahui bahwa lebih dari separuh masyarakat Kelurahan Lubuk Buaya yaitu sebanyak 57 responden memiliki tindakan PSN baik $(51,8 \%)$. Sisanya 53 responden memiliki tindakan PSN yang kurang baik (48,2\%).

Tabel 4. Hubungan Tindakan PSN dengan Keberadaan Larva Vektor DBD

\begin{tabular}{lccccc}
\hline \multirow{2}{*}{$\begin{array}{c}\text { Tindakan } \\
\text { PSN }\end{array}$} & \multicolumn{4}{c}{ Keberadaan Larva } & Jumlah \\
\cline { 2 - 6 } & $\mathrm{f}$ & $\%$ & $\mathrm{f}$ & $\%$ & $\mathrm{f}(\%)$ \\
\hline Kurang & 28 & 52,83 & 25 & 47,17 & $53(48,2)$ \\
baik & 11 & 19,3 & 46 & 80,7 & $57(51,8)$ \\
Baik & 39 & 35,45 & 71 & 64,55 & $110(100)$ \\
\hline Jumlah & & & & & \\
\hline
\end{tabular}

Berdasarkan Tabel 4 dapat dilihat bahwa tindakan responden dengan kategori kurang baik dan terdapat jentik di rumahnya adalah sebesar 52,83\%, sedangkan tindakan responden kategori baik dan terdapat jentik di rumahnya yaitu sebesar 19,3\%. Hasil uji statistik didapatkan nilai $p=0,001$. Hal ini menunjukkan bahwa terdapat hubungan yang bermakna antara tindakan PSN responden dengan keberadaan jentik vektor DBD.

\section{PEMBAHASAN}

\section{Keberadaan dan Kepadatan Vektor DBD}

Berdasarkan Tabel 1 didapatkan nilai $\mathrm{HI}$ $35,45 \%$, Cl 13,41\% dan BI 50\%. Nilai ini menunjukkan bahwa kepadatan dan penyebaran di Kelurahan Lubuk Buaya tinggi, karena menurut WHO pada tahun 1972 dalam Queensland tahun 2011, suatu wilayah dikatakan mempunyai kepadatan dan penyebaran tinggi serta beresiko tinggi untuk penularan DBD jika $\mathrm{HI} \geq 10 \%, \mathrm{Cl} \geq 5 \%, \mathrm{BI}>50 \%$ dan Df $>5 .{ }^{10}$ Hasil ini lebih tinggi dibandingkan yang diperoleh Yuni pada tahun 2013 di Kelurahan Jati Kota Padang dengan HI $=25,71 \%, \mathrm{Cl}=13,64 \%$, dan $\mathrm{BI}=26 \%$ dengan $D f=4$ (kategori sedang). ${ }^{11}$ Keberadaan dan kepadatan larva vektor penular DBD yang tergolong tinggi ini dipengaruhi oleh faktor risiko lingkungan dan faktor risiko manusia. Faktor risiko lingkungan, salah satunya yaitu ketinggian. Kelurahan Lubuk Buaya berada di ketinggian $\pm 2 \mathrm{~m}$ diatas permukaan laut yang termasuk dataran rendah. Menurut WHO tahun 2009, ketinggian merupakan faktor penting yang membatasi penyebaran Aedes spp. Dataran rendah (kurang dari $500 \mathrm{~m}$ ) memiliki tingkat populasi nyamuk dari sedang hingga tinggi. ${ }^{2}$

Faktor risiko manusia yang mempengaruhi keberadaan dan kepadatan vektor DBD yaitu kepadatan penduduk, mobilitas dan perumahan. Jumlah penduduk di Kelurahan Lubuk Buaya adalah 19.653 jiwa dengan luas wilayah $3,67 \mathrm{~km}^{2}$, sehinga didapatkan kepadatan pnduduk per $\mathrm{km}^{2}$ sebesar 5.355. Menurut Undang-undang nomor 56/PRP/1960 dalam Kementrian Agrarria dan Tata Ruang/Badan Pertahanan Nasional, tingkat kepadatan lebih besar dari 401 jiwa/ km² menandakan bahwa kepadatan penduduk sangat padat. ${ }^{12} \mathrm{Hal}$ ini menunjukkan bahwa kepadatan penduduk di Kelurahan Lubuk Buaya adalah sangat padat. Hal ini dapat memudahkan penyebaran penyakit DBD. Hasil pengamatan menunjukkan perumahan di Kelurahan Lubuk Buaya juga tidak teratur, yang mana satu rumah berdempet dengan rumah lain. Hal ini mempermudah nyamuk berpindah dari satu rumah ke rumah lainnya sehingga sangat berperan dalam penyebaran penyakit DBD.

Menurut WHO tahun 2009, penyakit yang berasal dari vektor nyamuk tidak akan ada bila nyamuk tidak muncul dan berkembang. Penyebab muncul dan berkembangnya nyamuk adalah adanya tempat perindukan nyamuk. TPA potensial sebagai tempat perindukannya (breeding place) adalah genangan air yang terdapat di dalam suatu wadah atau kontainer. ${ }^{2}$ Hal ini didukung dengan data 
ditemukannya beberapa kontainer yang positif jentik vektor DBD dalam penelitian ini, sehingga didapatkan $\mathrm{Cl}=13,41 \%$

Tabel 2 menunjukkan bahwa jentik vektor DBD lebih banyak pada kontainer yang berada di dalam rumah dibandingkan di luar rumah. Hal ini terlihat dari kontainer di dalam rumah yang positif jentik 16,67\% sedangkan kontainer di luar rumah dan positif jentik 9,34\%. Penelitian oleh Putri pada tahun 2013 menunjukkan hal yang sama yaitu kontainer yang terletak di dalam rumah dan positif jentik 16,15\% sedangkan kontainer di luar rumah dan positif jentik $5,72 \%{ }^{13} \mathrm{Hal}$ ini terjadi karena di dalam rumah banyak terdapat tempat yang kondusif bagi vektor DBD untuk berkembang. Adanya TPA yang digunakan berkaitan dengan kegiatan sehari-hari seperti memasak, mencuci dan mandi umumnya lebih banyak berada di dalam rumah. ${ }^{8}$

Tabel 3 menunjukkan spesies larva Aedes aegypti lebih banyak ditemukan di dalam rumah. Tempat perindukan utama Ae. aegypti adalah tempattempat berisi air bersih yang berada di dalam rumah atau berdekatan dengan rumah penduduk. Tempat perindukan tersebut berupa tempat perindukan buatan manusia, seperti tempayan/ gentong tempat penyimpan air minum, bak mandi, dan tempat penampungan air lainnya. $^{9}$

Kontainer di dalam rumah yang terbanyak mengandung jentik vektor DBD adalah tempat penampungan dispenser sebanyak 17 kontainer (44,74\%). Penelitian Riandi et al pada tahun 2011 mengenai sebaran jentik nyamuk Aedes spp. di Kecamatan Tawang Kota Tasikmalaya mendapatkan bahwa wadah air terbanyak kedua yang positif jentik setelah bak mandi adalah dispenser. Hal ini terjadi karena banyak rumah tangga yang tidak memperhatikan kontainer ini dan membiarkannya terisi air. Hal ini tentu sangat berpotensi sebagai tempat perkembangbiakan nyamuk. ${ }^{14}$

\section{Tindakan Pemberantasan Sarang Nyamuk}

Berdasarkan Gambar 1 diketahui bahwa 57 responden $(51,82 \%)$ memiliki tindakan PSN baik dan 53 responden $(48,18 \%)$ memiliki tindakan PSN kurang baik. Nilai ini menunjukkan bahwa jumlah responden dengan tindakan kurang baik hanya sedikit dibawah responden dengan tindakan baik. Penelitian Handayani pada tahun 2007 menunjukkan hal yang sama, dimana responden dengan tindakan PSN baik sebanyak $65,52 \%$ dan kurang baik $34,48 \%$. $^{15}$ Meskipun sebahagian besar pelaksanaan PSN termasuk dalam kategori baik, akan tetapi masih terdapat responden yang berada dalam kategori kurang baik. Hal ini dapat berdampak pada semakin banyaknya TPA yang berpotensi menjadi tempat perindukan nyamuk sehingga dapat meningkatkan terjadinya kasus DBD. ${ }^{8}$

Tindakan pelaksanaan 3M Plus yang masih kurang baik ini menunjukkan bahwa masih kurangnya kesadaran masyarakat terhadap pentingnya menjaga kebersihan rumah dan lingkungan sekitar tempat tinggal agar dapat mencegah terjadinya penyakit DBD. Notoatmodjo pada tahun 2007 menyebutkan bahwa perilaku masyarakat mempunyai pengaruh terhadap lingkungan karena lingkungan merupakan lahan untuk perkembangan perilaku tersebut. ${ }^{16}$ Kurang baiknya perilaku/tindakan PSN DBD masyarakat akan menciptakan lingkungan yang kondusif bagi perkembangbiakan nyamuk Ae. aegypti.

\section{Hubungan Tindakan Pemberantasan Sarang Nyamuk dengan Keberadaan Larva Vektor DBD}

Tabel 4 menunjukkan adanya hubungan yang bermakna antara tindakan PSN responden dengan keberadaan jentik vektor DBD, dimana responden dengan tindakan kurang baik dan terdapat jentik di rumahnya adalah sebesar 52,83\%, sedangkan responden dengan tindakan baik dan terdapat jentik di rumahnya yaitu sebesar 19,3\%. Penelitian Booroto et al pada tahun 2012 menunjukkan hal yang sama, dimana responden dengan tindakan kurang baik dan positif jentik adalah sebesar 70,37\%, sedangkan responden dengan tindakan baik dan positif jentik sebesar 28,26\%. Hal ini disebabkan responden seringkali hanya membersihkan TPA yang dapat dijangkau saja, padahal tindakan PSN membersihkan TPA di semua tempat untuk menekan perkembangbiakan nyamuk Aedes spp.. ${ }^{17}$ Aspek sanitasi lingkungan yang paling dominan berhubungan dengan keberadaan jentik vektor DBD adalah PSN. ${ }^{18}$ 
Hasil penelitian Setyobudi pada tahun 2011 menunjukkan partisipasi masyarakat dalam kegiatan PSN sangat berpengaruh dengan keberadaan jentik nyamuk Ae. aegypti. Kurangnya penyuluhan dari tenaga medis kepada masyarakat dapat menyebabkan ketidaktahuan masyarakat tentang bahaya yang ditimbulkan oleh penyakit DBD sehingga sikap dan tindakan masyarakat tetap buruk dalam mencegah terjadinya DBD. ${ }^{19} \mathrm{Hal}$ ini didukung dengan penelitian Yudhastuti dan Vidiyani pada tahun 2005, tentang pengetahuan dan tindakan dalam mengurangi atau menekan kepadatan jentik nyamuk Aedes spp. mempunyai hubungan dengan keberadaan jentik nyamuk Aedes spp.. ${ }^{20}$ Upaya instansi terkait, seperti Puskesmas dalam penyuluhan tentang PSN perlu ditingkatkan.

\section{KESIMPULAN}

Keberadaan dan kepadatan larva vektor DBD di Kelurahan Lubuk Buaya Kota Padang tergolong tinggi. Lebih dari separuh responden melakukan tindakan PSN yang baik. Terdapat hubungan yang bermakna antara tindakan PSN dengan keberadaan larva vektor DBD.

\section{DAFTAR PUSTAKA}

1. Cucuwaningsih. Dengue clinical and epidemiology review. Medicinus Jurnal Kedokteran Universitas Pelita Harapan. 201;8(3):27-35.

2. WHO. Dengue guidelines for diagnosis, treatment, prevention, and control. Geneva:WHO;2009.

3. Kemenkes RI. Demam berdarah dengue. Jakarta: Buletin Jendela Epidemiologi.2010; 2.

4. Kemenkes RI. Profil kesehatan Indonesia 2012 Jakarta: Kementrian Kesehatan Republik Indonesia; 2013.

5. Dinkes Propinsi Sumatera Barat. Data DBD Propinsi Sumatera Barat tahun 2008-2012. Padang: Dinas Kesehatan Propinsi sumatera barat; 2013

6. Dinkes Kota Padang. Profil Kesehatan Kota Padang 2011-2013. Padang: Dinas Kesehatan Kota Padang; 2013.

7. Sukowati S. Masalah vektor demam berdarah dengue (DBD) dan pengendaliannya di Indonesia. Dalam: Pusat Data dan Surveilans Epidemiologi
Kemenkes RI. Buletin Jendela Epidemiologi. Volume ke-2. Kemenkes RI; 2010.hlm.26-30.

8. Kemenkes RI. Modul pengendalian demam berdarah dengue. Jakarta: Ditjen P2PL; 2011.

9. Djakaria S, Sungkar S. Vektor penyakit virus, riketsia, spiroketa dan bakteri. Dalam: Sutanto I, Ismid IS, Sjarifuddin PK, Sungkar S, editor (penyunting).. Buku Ajar Parasitologi Kedokteran. Edisi ke-4. Jakarta: Balai Penerbit FK UI; 2008. hlm. 265-73.

10. Queensland Government. Queensland dengue management plan 2010-2015. Communicable Diseases Branch Queensland Health; 2011.

11. Yuni AM. Hubungan tingkat pengetahuan dan tindakan pencegahan demam berdarah dengue (DBD) dengan keberadaan vektor DBD di Kelurahan Jati Kota Padang (skripsi). Padang: Fakultas Kedokteran Universitas Andalas; 2013.

12. Kementrian Agraria dan Tata Ruang/Badan Pertahanan Nasional. Undang-undang nomor 56 tahun 1960. [serial online] 2015 (diunduh 10 Januari 2015). Tersedia dari: URL: HYPERLINK http://www.bpn.go.id/Publikasi/PeraturanPerundangan/Undang-Undang/undangundang-nomor-56-tahun-1960-919

13. Putri MD. Hubungan tindakan pemberantasan sarang nyamuk dengan keberadaan jentik vektor chikungunya di Kampung Taratak Paneh Kota Padang (skripsi). Padang: Fakultas Kedokteran Universitas Andalas; 2014.

14. Riandi MU, Ipa M, Hendri J. Sebaran jentik nyamuk Aedes spp di Kecamatan Tawang Kota Tasikmalaya. Loka Penelitian dan Pengembangan Pengendalian Penyakit Bersumber Binatang Ciamis Kampung Kamurang Desa Babakan Kecamatan Pangandaran Kabupaten Ciamis Jawa Barat. [serial online] 2011 (diunduh 30 Desember 2014). Tersedia dari: URL: HYPERLINK http://www.researchgate.net/publication/25792881 5 Sebaran Jentik Nyamuk Aedes spp. di Keca matan Tawang Kota Tasikmalaya.

15. Handayani I. Hubungan tindakan pencegahan Demam Berdarah Dengue dengan keberadaan larva vektor demam berdarah dengue di Kelurahan Aur Kuning Kota Bukittinggi (skripsi). Padang: Fakultas Kedokteran Andalas; 2007. 
16. Notoatmodjo S. Domain perilaku. Promosi kesehatan dan ilmu perilaku. Jakarta: Rineka Cipta; 2007.

17. Booroto AT, Joseph WBS, Tucunan A. Relationship between measures eradication mosquito nest (PSN) with existence larvae mosquito aedes sp. in environmental areas 1 teling atas village, District of Wanea Manado City. Media Kesehatan Jurnal Kesehatan Masyarakat Universitas Sam Ratulangi. [serial online] 2013 (diunduh 2 Juli 2014). Tersedia dari: URL: HYPERLINK http://fkm.unsrat.ac.id/?p=604.

18. Zulkarnaini, Siregar YI, Dameria. Hubungan kondisi sanitasi lingkungan rumah tangga dengan keberadaan jentik vektor dengue di
Daerah Rawan Demam Berdarah Dengue Kota Dumai Tahun 2008. Journal of Environmental Science. 2009;3(2):115-24.

19. Setyobudi A. Faktor-faktor yang berhubungan dengan keberadaan jentik nyamuk di daerah endemik DBD di Kelurahan Sananwetan Kecamatan Sananwetan Kota Blitar. [serial online] 2011 (diunduh 30 Desember 2014). Tersedia dari: URL: HYPERLINK (http://journal.unsil.ac.id/jurnal/ prosiding/9/930-agus 30.pdf.pdf).

20. Yudhastuti R, Vidiyani A. Hubungan kondisi lingkungan, kontainer, dan perilaku masyarakat dengan keberadaan jentik nyamuk Aedes aegypti di daerah endemis demam berdarah dengue Surabaya. Jurnal Kesehatan Lingkungan. 2005; $2(1): 170-82$. 